\title{
Wet and dry deposition of mineral dust particles in Japan: factors related to temporal variation and spatial distribution
}

\author{
K. Osada ${ }^{1}$, S. Ura ${ }^{1, *}$, M. Kagawa ${ }^{1}$, M. Mikami ${ }^{2}$, T. Y. Tanaka ${ }^{2}$, S. Matoba ${ }^{3}$, K. Aoki ${ }^{4}$, M. Shinoda ${ }^{5}$, Y. Kurosaki ${ }^{5}$, \\ M. Hayashi ${ }^{6}$, A. Shimizu ${ }^{7}$, and M. Uematsu ${ }^{8}$ \\ ${ }^{1}$ Graduate School of Environmental Studies, Nagoya University, Chikusa-ku, Furo-cho, Nagoya, 464-8601, Japan \\ ${ }^{2}$ Meteorological Research Institute, Nagamine 1-1, Tsukuba, 305-0052, Japan \\ ${ }^{3}$ Institute of Low Temperature Science, Hokkaido University, Kita-ku, Kita 19 Jo, Nishi 8 chome, Sapporo, 060-0819, Japan \\ ${ }^{4}$ Department of Earth Science, University of Toyama, Gofuku 3190, Toyama, 930-0887, Japan \\ ${ }^{5}$ Arid Land Research Center, Tottori University, Hamasaka 1390, Tottori, 680-0001, Japan \\ ${ }^{6}$ Department of Earth System Science, Fukuoka University, Jounan-ku, Nanakuma 8-19-1, Fukuoka, 814-0180, Japan \\ ${ }^{7}$ National Institute for Environmental Studies, Onogawa 16-2, Tsukuba, 305-0053, Japan \\ ${ }^{8}$ Atmosphere and Ocean Research Institute, The University of Tokyo, Kashiwanoha 5-1-5, Kashiwa, 277-8564, Japan \\ *now at: Hokuriku Electric Power Company, Japan
}

Correspondence to: K. Osada (kosada@nagoya-u.jp)

Received: 21 June 2013 - Published in Atmos. Chem. Phys. Discuss.: 23 August 2013

Revised: 3 December 2013 - Accepted: 16 December 2013 - Published: 29 January 2014

\begin{abstract}
Recent ground networks and satellite remotesensing observations have provided useful data related to spatial and vertical distributions of mineral dust particles in the atmosphere. However, measurements of temporal variations and spatial distributions of mineral dust deposition fluxes are limited in terms of their duration, location, and processes of deposition. To ascertain temporal variations and spatial distributions of mineral dust deposition using wet and dry processes, weekly deposition samples were obtained at Sapporo, Toyama, Nagoya, Tottori, Fukuoka, and Cape Hedo (Okinawa) in Japan during October 2008-December 2010 using automatic wet and dry separating samplers. Mineral dust weights in water-insoluble residue were estimated from Fe contents measured using an X-ray fluorescence analyser. Wet and dry deposition fluxes of mineral dusts were both high in spring and low in summer, showing similar seasonal variations to frequency of aeolian dust events (Kosa) in Japan. For wet deposition, highest and lowest annual dust fluxes were found at Toyama $\left(9.6 \mathrm{~g} \mathrm{~m}^{-2} \mathrm{yr}^{-1}\right)$ and at Cape Hedo $\left(1.7 \mathrm{~g} \mathrm{~m}^{-2} \mathrm{yr}^{-1}\right)$ as average values in 2009 and 2010. Higher wet deposition fluxes were observed at Toyama and Tottori, where frequent precipitation (> 60\% days per month) was observed during dusty seasons. For dry deposition among Toyama, Tottori, Fukuoka, and Cape Hedo,
\end{abstract}

the highest and lowest annual dust fluxes were found respectively at Fukuoka $\left(5.2 \mathrm{~g} \mathrm{~m}^{-2} \mathrm{yr}^{-1}\right)$ and at Cape Hedo $\left(2.0 \mathrm{~g} \mathrm{~m}^{-2} \mathrm{yr}^{-1}\right)$ as average values in 2009 and 2010. The average ratio of wet and dry deposition fluxes was the highest at Toyama (3.3) and the lowest at Hedo (0.82), showing a larger contribution of the dry process at western sites, probably because of the distance from desert source regions and because of the effectiveness of the wet process in the dusty season.

Size distributions of refractory dust particles were obtained using four-stage filtration: $>20,>10,>5$, and $>1 \mu \mathrm{m}$ diameter. Weight fractions of the sum of $>20 \mu \mathrm{m}$ and 10 $20 \mu \mathrm{m}$ (giant fraction) were higher than $50 \%$ for most of the event samples. Irrespective of the deposition type, the giant dust fractions generally decreased with increasing distance from the source area, suggesting the selective depletion of larger giant particles during atmospheric transport. Based on temporal variations of $\mathrm{PM}_{\mathrm{c}}(2.5<D<10 \mu \mathrm{m})$, ground-based lidar, backward air trajectories, and vertical profiles of potential temperatures, transport processes of dust particles are discussed for events with high-deposition and low-deposition flux with high $\mathrm{PM}_{\mathrm{c}}$. Low dry dust depositions with high $\mathrm{PM}_{\mathrm{c}}$ concentrations were observed under stronger $\left(5 \mathrm{~K} \mathrm{~km}^{-1}\right)$ stratification of potential temperature with thinner and lower 
$(<2 \mathrm{~km})$ dust distributions because the $\mathrm{PM}_{\mathrm{c}}$ fraction of dust particles only survived after depletion of giant dust particles by rapid gravitational settling at the time they reach Japan. In contrast, transport through a thicker $(>2 \mathrm{~km})$ dust layer with weak vertical gradient of potential temperature carry more giant dust particles to Japan. Because giant dust particles are an important mass fraction of dust accumulation, especially in the North Pacific, which is known as a high-nutrient, lowchlorophyll (HNLC) region, the transport height and fraction of giant dust particles are important factors for studying dust budgets in the atmosphere and their role in biogeochemical cycles.

\section{Introduction}

Mineral dust particles in the atmosphere play an important role in meteorological effects and bio-geochemical cycles (Mahowald et al., 2005; McTanish and Strong, 2007; Shao et al., 2011). The meteorological and climatic importance of mineral dust particles includes the absorption and scattering of radiation in the atmosphere and the modifications of the optical properties of clouds and snow/ice surfaces (Tegen, 2003; Aoki et al., 2006). Atmospheric mineral dust also contributes to transportation of nutrients such as phosphorus $(\mathrm{P})$, iron $(\mathrm{Fe})$, and nitrate $\left(\mathrm{NO}_{3}^{-}\right)$to marine and terrestrial ecosystems (Nishikawa et al., 1991; Okin et al., 2004; Jickells et al., 2005). To evaluate these effects over regional and global scales, temporal variation and spatial distributions of deposition fluxes of mineral dusts must be ascertained. In addition to direct measurements at the ground, observations using ground-based and space-borne Lidars provide vertical and spatial distributions of mineral dust particles in the atmosphere (e.g. Shimizu et al., 2004; Su and Toon, 2011; Mona et al., 2012). However, data related to temporal variations and spatial distributions of mineral dust flux to the ground are limited (Washington and Wiggs, 2011; Schulz et al., 2012). Using appropriate deposition velocities and scavenging ratios with measured data on aerosols and precipitation, Duce et al. (1991) estimated the global dust deposition flux, providing insight into a global map of dust deposition over the ocean. Nevertheless, details of the regional flux gradient and temporal variations remain unknown.

Asian mineral dust particles derived from Chinese and Mongolian deserts are transported by westerly winds to the northwestern Pacific. In Japan, located at the western edge of the North Pacific, visibility-reducing aeolian dust events, called Kosa in Japanese, occur in spring (Koizumi, 1932; Arao et al., 2003). Kosa events have been studied not only in relation to atmospheric sciences but also for their impact on public health (e.g. Onishi et al., 2012). Routine forecasts of aeolian dust concentrations over Japan began in 2004 (Kinoshita and Maki, 2009) based on a numerical simulation model of the Japan Meteorological Agency: MASINGAR
(Tanaka et al., 2003). To improve the performance of dust concentration forecasts and the estimation of climatic effects of dust in the atmosphere, validation data on dust simulation are necessary not only for atmospheric concentration but also for dust deposition flux.

Dust particles in the atmosphere are deposited onto the Earth's surface accompanying precipitation (wet process) or without precipitation (dry process) (Lovett, 1994). The process of particle dry deposition consists of (1) aerodynamic transport and gravitational sedimentation to a stagnant thin layer adjacent to the ground surface, (2) Brownian transport, inertial impaction, and gravitational settling across the thin air layer to the surface, and (3) uptake at the surface (Zufall and Davidson, 1998; Seinfeld and Pandis, 2006). Depending on the particle size, the dominant factor differs: Brownian diffusion is effective only for sub-micrometer particles. Gravitational settling is important in the super-micrometer size range. In addition, particles of $10-50 \mu \mathrm{m}$ are unique because of the importance of inertial properties related to gravitational settling (Aluko and Noll, 2006). Although processes included in various numerical simulation models are similar, their larger size and their size bins in the super-micrometer range differ (Uno et al., 2006).

Continuous multi-year data of deposition flux have been reported for dusts transported from desert areas such as central and eastern Asia (Inoue and Naruse, 1987; Yabuki et al., 2005; Hsu et al., 2009; Sun et al., 2003; Ta et al., 2004; Zhang et al., 1993), North America (Reheis, 2006), and the Middle East and Sahara (Ganor et al., 2003; Offer and Goossens, 2004; Pye, 1992; Nihlén et al., 1995; Loye-Pilot and Martin, 1996). Data of shorter (nearly 1 yr or event basis) periods have been reported much more (e.g. Inomata et al., 2009a; Uematsu et al., 1985, 2003). However, most of such data are unsatisfactory for the validation of modern numerical model simulation of dust transport and deposition because of one or more reasons related to (1) lack of separation between wet and dry processes, (2) worse time resolution (monthly) of the sampling period, (3) urban local dust contamination, (4) use of scavenging ratios to estimate wet deposition (namely, indirect data), and (5) single point measurements. These issues will be addressed briefly.

Numerical simulations of atmospheric aerosol particles have been validated by comparison of various atmospheric observation data such as Lidar (Uno et al., 2006) and optical thickness (Takemura et al., 2000). According to results from inter-comparison of dust transport models over Asia (Uno et al., 2006), improving treatments on dust removal is an important issue to make progress on the models. However, measurements of dust deposition are not so simple because of the difficulty of sampling, especially for dry processes (Washington and Wiggs, 2011; Huneeus et al., 2011). Although the time periods of precipitation or non-precipitation are readily separable using a precipitation sensor, reliable sampling of the amount and size distribution for dry deposition are difficult because of variable collection efficiency depending 
on the particle size, wind speed, and the collector shape (Goossens, 2005, 2007). Evaluations and improvements of various dry deposition collectors have been reported, but no perfect method of dry deposition exists (Vallack and Chadwick, 1992; Sow et al., 2006; Goossens and Rajot, 2008).

For comparison with model outputs, the time resolution of observations is also a critical issue. Time scales of dust storms as well as precipitation processes are from sub-hourly to daily. Therefore, the dust deposition collection period are expected to have a similar time range that is much shorter than monthly. Another sampling issue is to avoid contributions of local dust contamination. Based on deposition measurements at multiple sites in the northeastern US, Tai et al. (1999) pointed out that urban sites exhibit larger numbers of coarse and irregular particles (possibly being windblown and anthropogenic sources) than non-urban sites do. Similarly, from observations at Tsukuba, an inland urban location (about $42 \mathrm{~km}$ from the nearest coast of the Pacific Ocean) in Japan, Inomata et al. (2009b) reported local contamination by dry dust deposition under high wind speed conditions.

Some reports describe studies using scavenging ratios to estimate wet dust deposition flux without collecting precipitation samples (Uematsu et al., 1985; Duce et al., 1991; Hsu et al., 2009). Estimating wet deposition flux from aerosol concentration and precipitation amount with a scavenging ratio is convenient for reducing the labor of precipitation sampling. However, the estimation method includes great uncertainty of assumptions applying a single scavenging ratio and uniform aerosol concentration for a precipitating air column.

Considering all the points presented above, process separation and multi-year, multi-site deposition data of mineral dusts are expected to be useful to validate numerical simulation models and to improve our knowledge of deposition processes. For this study, we conducted continuous $2.2 \mathrm{yr}$, weekly wet and dry deposition sampling at six sites in Japan. We present temporal and geographical variations of wet and dry dust deposition and discuss their controlling factors.

\section{Observation sites, experiments, and meteorological data}

Observation sites were selected to meet various criteria as described above. To collect dust deposition transported by westerly winds to Japan, the best location is the western edge of the Japanese archipelago. Furthermore, to minimise local dust contribution, the sampling sites are better located at non-urban sites near the ocean. In practice, an important factor was the employment of capable assistants who conducted sampler maintenance as well as geographical balance of the sites. Wet and dry dust deposition samples were collected weekly at Sapporo $\left(43.08^{\circ} \mathrm{N}, 141.34^{\circ} \mathrm{E}\right)$, Toyama $\left(36.70^{\circ} \mathrm{N}\right.$, $\left.137.19^{\circ} \mathrm{E}\right)$, Nagoya $\left(35.16^{\circ} \mathrm{N}, 136.97^{\circ} \mathrm{E}\right)$, Tottori $\left(35.54^{\circ} \mathrm{N}\right.$, $\left.134.21^{\circ} \mathrm{E}\right)$, Fukuoka $\left(33.55^{\circ} \mathrm{N}, 130.36^{\circ} \mathrm{E}\right)$, and Cape Hedo $\left(26.86^{\circ} \mathrm{N}, 128.25^{\circ} \mathrm{E}\right.$, Okinawa, see Fig. 1), using samplers

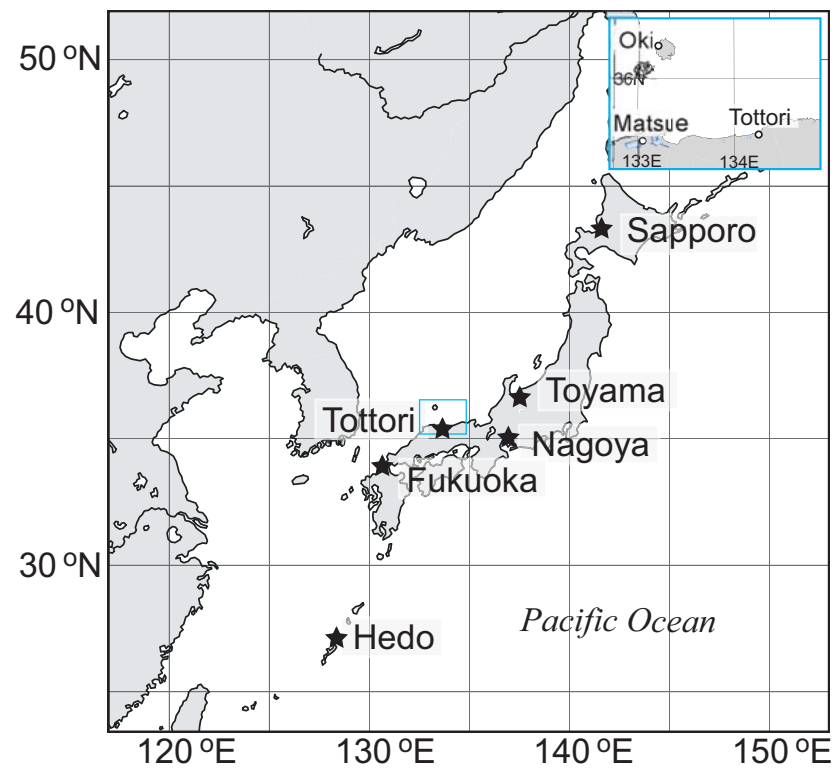

Fig. 1. Map showing observation sites. The blue rectangle in the upper right corner is an enlargement of the map near Tottori, showing positions of Oki Island $\left(\mathrm{PM}_{10}\right.$ and $\mathrm{PM}_{2.5}$ measurements by EANET) and Matsue (Lidar observation by NIES).

that automatically separate wet and dry deposition, each of which is equipped with a precipitation sensor (US-330H for cold environment with a heater on precipitation funnel and US-330 for warm environment without a heater; Ogasawara Keiki Seisakusho Co. Ltd.). Distances of the sites from the nearest coast were $15 \mathrm{~km}$ at Sapporo, $6 \mathrm{~km}$ at Toyama, $10 \mathrm{~km}$ at Nagoya, $0.7 \mathrm{~km}$ at Tottori, $5 \mathrm{~km}$ at Fukuoka, and $0.2 \mathrm{~km}$ at Cape Hedo. The wet and dry samplers were placed in open areas on the rooftops of buildings, not on the ground, to minimise local soil contamination. To melt solid precipitation during the cold season, a ring heater was used at Sapporo, Toyama, and Tottori. The precipitation sensor detects precipitation at about $0.5 \mathrm{~mm} \mathrm{~h}^{-1}$ and starts a cover to move from a precipitation funnel to a dry deposition collector.

The wet deposition sample water was collected using a plastic funnel $(20 \mathrm{~cm}$ diameter) and stored in a pre-cleaned wide-mouth $3 \mathrm{~L}$ polyethylene bottle in a refrigerator in the sampler. At the time of bottle replacement, the funnel was washed with $50 \mathrm{~mL}$ of ultrapure water to ensure that all dust on the funnel surface was transferred. Benzalkonium chloride (Osvan) was added to sample water as a $>0.01 \%$ solution for sterilization.

The dry deposition sample was collected using a precleaned plastic bag (Unipack L-8; Seisan Nipponsha Ltd.) fitted inside a deposition collector $(20 \mathrm{~cm}$ diameter, $40 \mathrm{~cm}$ deep) during the non-precipitating period. The plastic bag was pre-cleaned using $40 \mathrm{~mL}$ of ethanol and $300 \mathrm{~mL}$ of ultrapure water. Clean plastic gloves were used to fit the plastic bag to the collector. The deposition collector with a plastic bag was used as a "surrogate surface" of dry deposition. As 
criticized in some reports (e.g. Goossens, 2007), collection of dust particles using this type of collector is not perfect for various size ranges, which potentially distorts the size distribution and collects a lesser amount of dust than an ideal collector. However, changing the plastic bag from the collector is easily accomplished, making them suitable for frequent replacement at many sites and for transport to Nagoya. We used the same collector for all sites, providing at least a uniform sampling condition to study the geographical distribution of dry deposition in Japan.

Wet and dry samples were normally replaced on every Wednesday. The standard collection period was 1 week. In addition to the normal operation, we added event samples collected for shorter (one to several days) intervals according to various forecasts on dust concentration in the atmosphere and precipitation. We used dust forecasts provided by MASINGAR (Tanaka et al., 2003) of JMA (http: //www.jma.go.jp/jp/kosafcst/index.html) and CFORS (Uno et al., 2003) of the Research Institute for Applied Mechanics/Kyushu University and the National Institute of Environmental Studies (http://www-cfors.nies.go.jp/ cfors/index-j. html), and other information at NRL/Monterey Aerosol Page (http://www.nrlmry.navy.mil/aerosol/) and a near realtime visibility map overlaid on an image from MODIS (Dr. Kurosaki at Tottori University, personal communications, 2009). Wet and dry deposition samples were stored at room temperature and were sent to the laboratory at Nagoya University once a month. Deposition sampling was started in October 2008, ending in early January 2011.

In the laboratory, wet deposition samples were filtered through preweighted, $25 \mathrm{~mm}$ diameter, $1.0 \mu \mathrm{m}$ pore-size $\mathrm{Nu}$ clepore filters (Whatman Co. Ltd.). For dry deposition samples, the plastic bag was washed with $100 \mathrm{~mL}(50 \mathrm{~mL}$ each) of ultrapure water to ensure that all dust in the bag was transferred. The dry deposition sample water was similarly filtered through Nuclepore filters $(1.0 \mu \mathrm{m}$ pore size). After drying the filters at $40{ }^{\circ} \mathrm{C}$ for $2 \mathrm{~h}$ in an electric oven, we weighed the filters using an electric microbalance (ER182A and GH252; A\&D Co. Ltd.).

The water-insoluble residual weight on the filter includes some biogenic components such as pollens, especially in spring. Mineral dust amounts were estimated from the relation between $\mathrm{Fe}$ and mineral dust amount on the filters, assuming Fe constituting $3.7 \%$ of mineral dust weight and that the relation does not vary among seasons or locations in Japan (Ura et al., 2011). Non-destructive X-ray fluorescence (MXF-1T; Kimoto Electric Co. Ltd.) analysis was used to measure Fe contents of the filter residue. Although elemental analysis using XRF provides $\mathrm{Al}$ and other elements, $\mathrm{Fe}$ was selected for our purposes because of (1) widest dynamic range of calibration response and (2) larger content than $\mathrm{Ti}$ that shows also wider dynamic range. A similar result of Xray attenuation for light elements such as $\mathrm{Al}$ and $\mathrm{Si}$ was also reported for mineral dust filters by Formenti et al. (2010). Reference materials were used for the calibration of Fe con- tent of filter residue, which were provided from Geological Survey of Japan (sediment sample from Lake Biwa: JLK-1, Imai et al., 1996 and marine sediment sample from southern Pacific Ocean: JMS-2, Terashima et al., 2002).

The average Fe content of $3.7 \%$ was calculated from linear correlation between Fe content and non-pollen weight of residue estimated from microscopic data (Ura et al., 2011). The average Fe content of the Earth's upper crust is 3.5\% (Taylor and McLennan, 1995). There might be some variations in the amount of Fe content depending on the size fraction (Cao et al., 2008; Wu et al., 2011) and on the source area (Formenti et al., 2011). Nonetheless, the average Fe content obtained by Ura et al. (2011) is consistent with the values reported for bulk Asian dust events in Korea (3.7\% at Seoul, Choi et al., 2001; 4.2-8.4\% at Seoul, Jeong, 2008) and in China (3.9-4.1\% at Beijing, Feng et al., 2008; 3.0-5.7\% at Beijing, Lue et al., 2010). In our sample treatment, both wet and dry deposition samples were washed with ultrapure water. Therefore, the water soluble fraction of $\mathrm{Fe}$ in the dust is lost during filtration. However, the fraction of water soluble $\mathrm{Fe}$ is expected to be very small compared to the total $\mathrm{Fe}$ content $(<1 \%$ of total $\mathrm{Fe}$ for Chinese loess, Schroth et al., 2009).

The dust size distribution was obtained using consecutive four-stage filtration: $>20 \mu \mathrm{m}$ using a nylon net filter $(25 \mathrm{~mm}$ diameter; Merck MilliPore), > $10 \mu \mathrm{m}$ ( $25 \mathrm{~mm}$ diameter, Nuclepore Track-Etched Membranes; Whatman), $>5 \mu \mathrm{m}(25 \mathrm{~mm}$ diameter, Nuclepore Track-Etched Membranes; Whatman), and $>1 \mu \mathrm{m}$ ( $25 \mathrm{~mm}$ diameter, Nuclepore Track-Etched Membranes; Whatman). Before applying fourstage filtration, the original filter with residue was heated at $750^{\circ} \mathrm{C}$ in an electric oven for $1 \mathrm{~h}$ to remove organic materials. It was gently loosened again by wetting and mixing with ethanol in an ultrasonic bath. Amounts of our filter residue samples were normally small (mostly below several milligrams). Therefore, multistage filtration was the best choice in a practical sense for measuring the size distribution. Heavier refractory samples (about $>1 \mathrm{mg}$ ) were selected for this filtration. The sample amount of filtration was restricted to approximately $1-2 \mathrm{mg}$ at the stage of $>10 \mu \mathrm{m}$ to prevent clogging pores. By heating at $750^{\circ} \mathrm{C}$, some mineral dusts would be dehydrated and their mineral forms changed, so that the weight and size for dust particles with non-refractory minerals might be decreased after treatment. Unfortunately, mineral compositions at the time of initial sampling were not known, and weight fractions of four-stage filtration were not corrected for heating effects.

Meteorological data such as precipitation were obtained from Japan Meteorological Agency (JMA) web sites (http: //www.data.jma.go.jp/obd/stats/etrn/index.php). The numbers of Aeolian dust (visibility-reducing lithometeor) events at and near the sites were referred from tables at JMA web sites (http://www.data.kishou.go.jp/obs-env/ kosahp/kosa_data_index.html). Precipitation data at Oku, the 
nearest (6 km distant) AMeDAS station, were used for Cape Hedo.

\section{Results and discussion}

\subsection{Temporal variation and special distribution of dust deposition fluxes}

Figure 2 shows the wet deposition flux of mineral dusts at six sites during October 2008-December 2010. Time intervals of flux presented in Fig. 2 are depicted with the original sampling duration. Therefore, the horizontal width is narrower for short-term sampling on a dust event predicted by Kosa event forecasts. Wet deposition flux was high in spring (February-May) and low in summer (July-September), irrespective of the site location and the year of observation. Temporal variations of wet dust deposition were not always synchronous among sites because of the migration of the precipitation region from west to east and the local effects of winter monsoon (drizzle precipitation) at Tottori, Toyama, and Sapporo. However, nearly simultaneous wet depositions at multiple sites were observed five times (late-January, late February, mid-March, mid-April, and late December) in 2009, and five times (mid-March, late March to early April, late April, late December) in 2010. These simultaneous depositions were roughly divided into two regional patterns as western to central parts and central to northern parts of Japan.

Wet dust deposition was often sporadic. Large wet fluxes were observed in Sapporo, Toyama, and Tottori, where drizzle precipitation was observed during the dusty season. In contrast, no such large sporadic flux was found at Nagoya and Cape Hedo, where drizzle precipitation was observed infrequently during the dusty season. Previously, Osada et al. (2011) reported that a combination of precipitation and Kosa events is necessary for the high wet-deposition flux of mineral dust based on an analysis of dust flux measurements, true colour MODIS satellite images, and vertical distributions of dust concentration from Lidar observations. To portray this point better geographically, Fig. 3 presents monthly wet deposition flux (red line), monthly number of days of Kosa events near the sites (gray vertical bar), and the monthly number percentage of precipitation days (blue line). The winter monsoon from Eurasian continent brings snow or drizzling rain at sites along the Sea of Japan, which engenders high frequency of precipitation in late fall to early spring (Barry and Chorley, 2003). The number of Kosa events was smallest at Sapporo, located in northern Japan. At Toyama, the tendency of monthly variation for wet deposition flux was similar to that of Kosa event days. Days of precipitation at Toyama were more than $60 \%$ during NovemberApril. In contrast, wet dust deposition flux was not so high in May 2010 when days of Kosa events were high (5 days), probably because of the low precipitation frequency $(40 \%)$. Therefore, the condition of frequent precipitation (>60\%)
Wet deposition
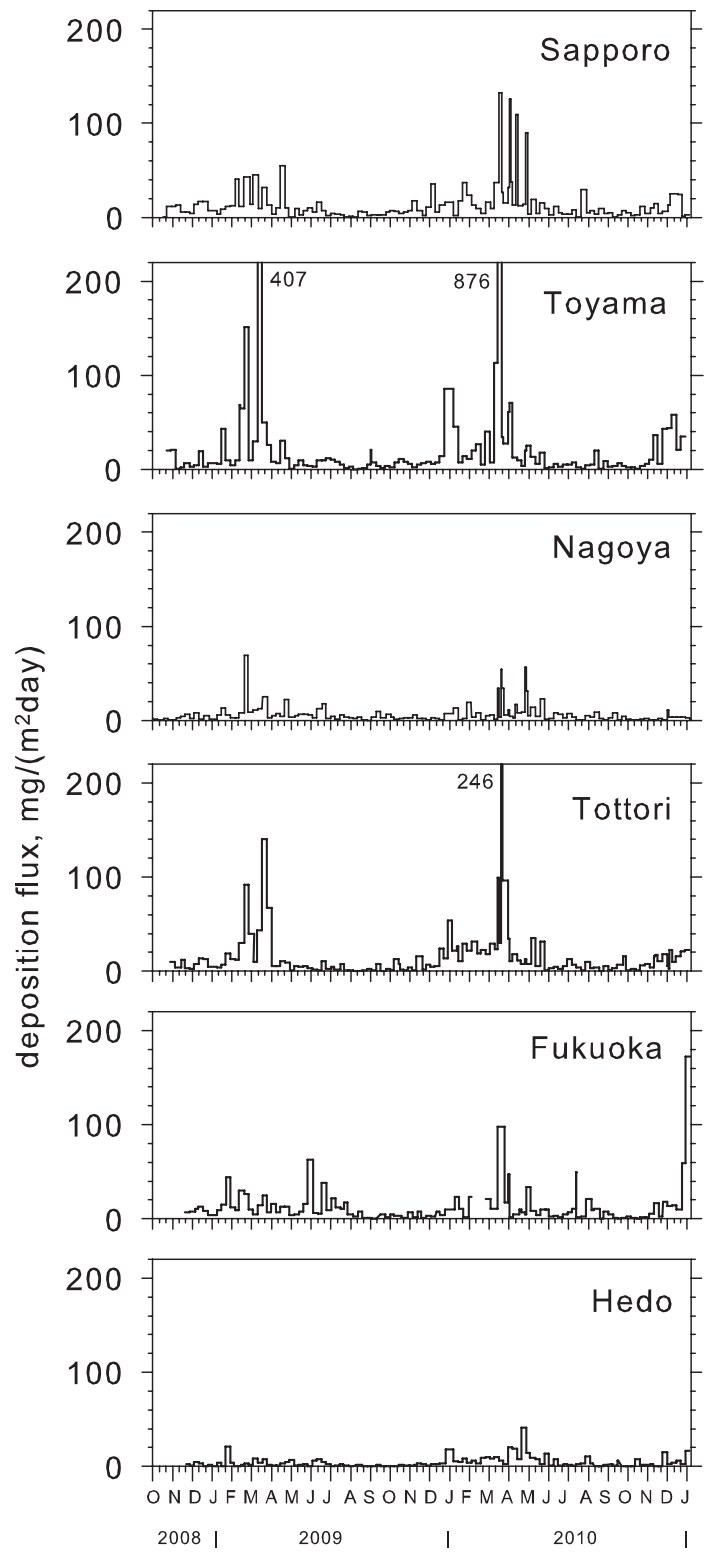

Fig. 2. Wet deposition flux $\left(\mathrm{mg} \mathrm{m}^{-2} \mathrm{day}^{-1}\right)$ of mineral dust during October 2008-December 2010.

is necessary to bring wet deposition of dusts. A similar tendency was also noted at Tottori. For Nagoya, Fukuoka, and Hedo, a tendency of monthly variation for wet deposition flux was not similar to that of Kosa events because of low precipitation frequency for many months, including the dusty season.

Annual wet deposition fluxes are presented in Table 1. Maximum (minimum) annual flux was obtained at Toyama (Hedo). The ratio of maximum to minimum was about 6 . As discussed above, places where precipitation was frequent during the dusty season received higher wet deposition of mineral dusts. The geographical distribution of annual wet 


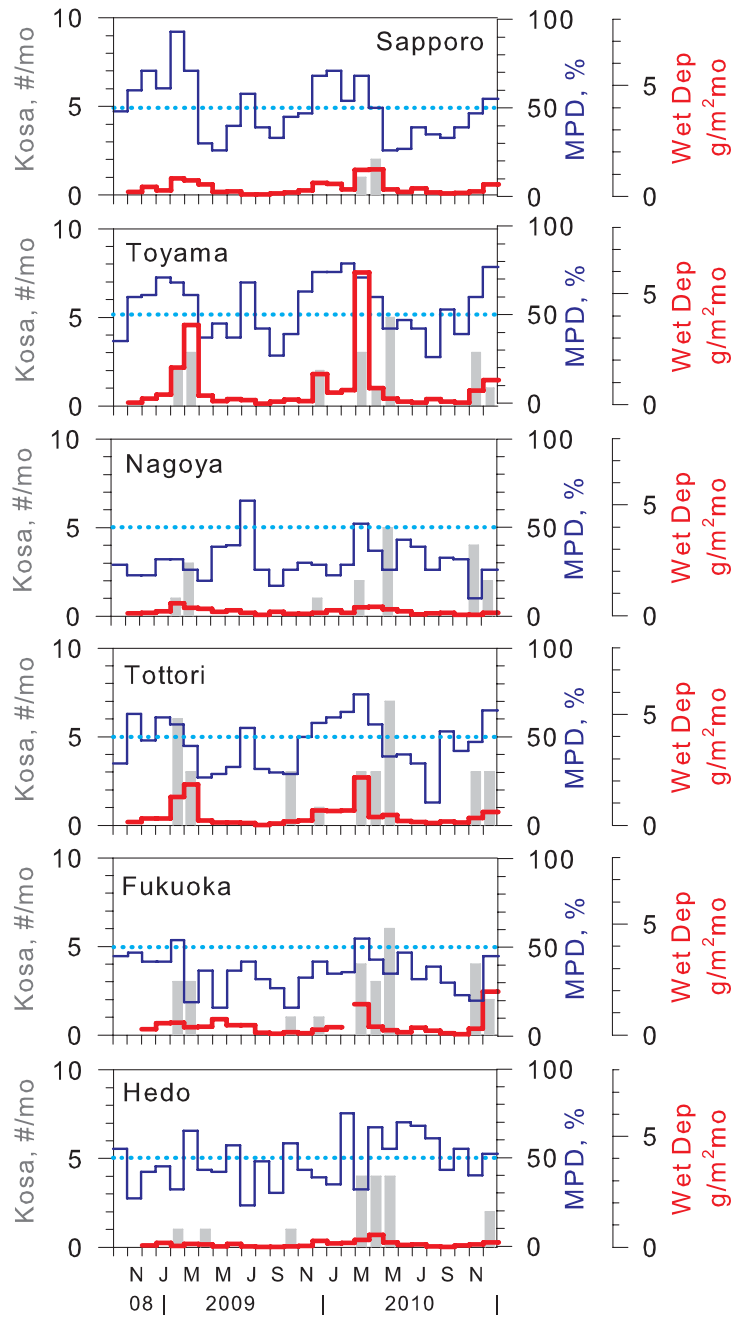

Fig. 3. Monthly numbers of aeolian dust event (Kosa) days near the sites (gray), monthly wet deposition fluxes (red), and monthly precipitation days in percent (blue). The horizontal light blue dotted line depicts $50 \%$ of monthly precipitation days.

flux in 2010 was almost identical to that in 2009, with smaller year-to-year variation at Nagoya and Tottori.

Figure 4 shows the dry deposition flux of mineral dusts at four sites during October 2008-December 2010. Dry deposition data at Sapporo and Nagoya were not used here because of the slight contribution of local urban dusts judging from microscopic analysis of filter residue samples, perhaps because of demolition and construction works and deflation of road side dusts near the sites. For other sites, the seasonal tendency of dry deposition fluxes was fundamentally the same as that for wet deposition, namely, high in spring and low in summer. Some sporadic dry deposition events at multiple sites were found three times in 2009 (21 February, 17 March, 19 May) and five times in 2010 (16 March, 21 March, 27 April, 4 May, 12 November; date as the widest distribution of Kosa reports based on a map of aeolian dusts

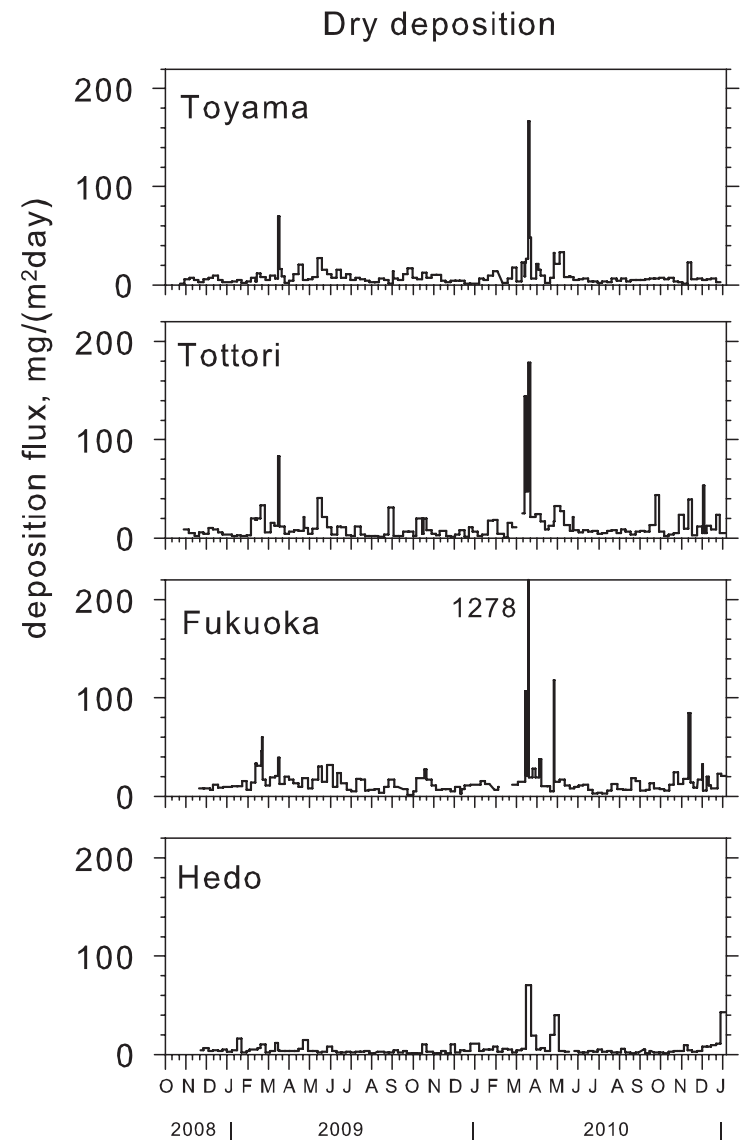

Fig. 4. Dry deposition flux $\left(\mathrm{mg} \mathrm{m}^{-2} \mathrm{day}^{-1}\right)$ of mineral dust during October 2008-December 2010.

by JMA web site). Small peaks around 13-20 May were noticeable at Toyama, Tottori and Fukuoka in May 2009 when no Kosa event was observed near the sites. Many other Kosa event days were observed in Japan, as reported by JMA: 11 and 15 February, 25 April, 8 May, 19 October, and 26 December in 2009, and 13 March, 2 April, 21 and 25 May, 3, 11 and 23 December in 2010. However, dry deposition flux for these days was high only at a single site or not notable as a peak at any site. Geographically limited scale advection of dust particles is one reason. However, other reasons might exist. A plausible reason is the contribution of non-dust particles to Kosa report because reduction of visibility (reported as Kosa or haze) occurs by suspending not only coarse dust particles but also anthropogenic fine particles. Widespread advection of air pollution with small dust particles might be regarded as Kosa. Indeed, Yamaguchi and Takemura (2011) reported that long-range transport of anthropogenic aerosols reduces recent visibility in western Japan. Anthropogenic aerosols are mostly fine particles, as represented by $\mathrm{PM}_{2.5}$, and include a non-dust component. Therefore, although advection of anthropogenic fine particles reduces visibility, it does not contribute to the amount of dust deposition. Another possible reason is related to dust size, as discussed below. 
Table 1. Annual deposition flux $\left(\mathrm{g} \mathrm{m}^{-2} \mathrm{yr}^{-1}\right)$ of mineral dust

\begin{tabular}{lrrr|rrr|rrr}
\hline & \multicolumn{3}{c|}{ Wet } & \multicolumn{3}{c|}{ Dry } & \multicolumn{3}{c}{ Wet/Dry ratio } \\
\cline { 2 - 10 } & 2009 & 2010 & AVG & 2009 & 2010 & AVG & 2009 & 2010 & AVG \\
\hline Sapporo & 4.12 & 5.36 & 4.74 & & & & & & \\
Toyama & 8.66 & 10.62 & 9.64 & 2.77 & 3.12 & 2.95 & 3.12 & 3.40 & 3.27 \\
Nagoya & 2.44 & 2.06 & 2.25 & & & & & & \\
Tottori & 5.11 & 5.93 & 5.52 & 3.22 & 4.86 & 4.04 & 1.58 & 1.22 & 1.36 \\
Fukuoka & 3.96 & 5.46 & 4.71 & 4.73 & 5.65 & 5.19 & 0.84 & 0.97 & 0.91 \\
Cape Hedo & 1.14 & 2.16 & 1.65 & 1.51 & 2.50 & 2.00 & 0.76 & 0.86 & 0.82 \\
\hline
\end{tabular}

The highest dry deposition flux among the sites was measured at Fukuoka $\left(1.28 \mathrm{~g} \mathrm{~m}^{-2} \mathrm{day}^{-1}\right)$ during 20 21 March 2010. Although sampling intervals differed, dry deposition fluxes for this event were also the highest at other sites: Toyama, $167 \mathrm{mg} \mathrm{m}^{-2} \mathrm{day}^{-1}$ for 20-22 March, Tottori, $169 \mathrm{mg} \mathrm{m}^{-2} \mathrm{day}^{-1}$ for 20-23 March, and Cape Hedo, $70 \mathrm{mg} \mathrm{m}^{-2}$ day $^{-1}$ for 17-24 March 2010. Many case studies were reported for this event because atmospheric dust concentrations were remarkably high over wide areas of China and Korea including not only the East China Sea but also the South China Sea (Bian et al., 2011; Li et al., 2011; Wang et al., 2011; Lin et al., 2012; Tatarov et al., 2012).

Table 1 presents dry annual dust flux and the wet/dry flux ratios. For dry deposition among Toyama, Tottori, Fukuoka, and Cape Hedo, the highest and lowest annual dust fluxes were found respectively at Fukuoka $\left(5.2 \mathrm{~g} \mathrm{~m}^{-2} \mathrm{yr}^{-1}\right)$ and at Cape Hedo $\left(2.0 \mathrm{~g} \mathrm{~m}^{-2} \mathrm{yr}^{-1}\right)$ as average values in 2009 and 2010. The ratio of maximum to minimum annual dry fluxes was about 3 , which is about half of that for wet deposition. The geographical distribution of annual dry flux in 2010 was almost identical to that recorded in 2009. The average ratio of wet/dry deposition fluxes was the highest at Toyama (3.3) and the lowest at Hedo (0.8), indicating a larger contribution of the dry process at western sites. Highest and lowest average total annual dust fluxes were found respectively at Toyama $\left(12.6 \mathrm{~g} \mathrm{~m}^{-2} \mathrm{yr}^{-1}\right)$ and at Cape Hedo $\left(3.7 \mathrm{~g} \mathrm{~m}^{-2} \mathrm{yr}^{-1}\right)$ in 2009 and 2010 .

Figure 5 presents monthly values of dry dust deposition flux (red line) and the monthly number of days for Kosa events observed near the sites (gray vertical). The annual number of Kosa events was higher at Tottori (13 days in 2009, 19 days in 2010) and Fukuoka ( 8 days in 2009, 19 days in 2010) than at the other sites. Dry deposition fluxes were also higher at Tottori and Fukuoka than at other sites (Table 1). Although the seasonal tendency of monthly dry deposition was roughly similar to that of monthly Kosa days, monthly dry deposition does not follow monthly Kosa days in some months, such as May 2010. As discussed for Fig. 4, some reasons engender mismatches between dry deposition and event number of Kosa, such as the contribution of anthropogenic fine aerosols and non-giant $(2.5<D<10 \mu \mathrm{m})$ dust particles that will be discussed in subsequent sections.
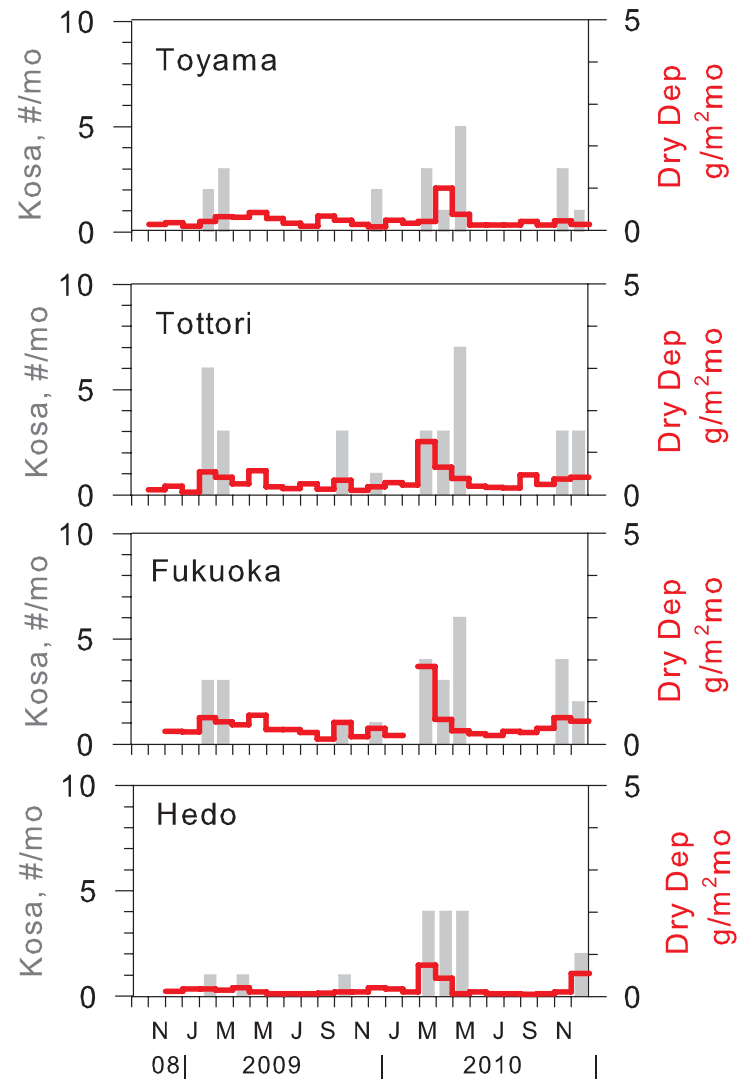

Fig. 5. Monthly numbers of Kosa days near the sites (gray) and monthly dry deposition fluxes (red).

\subsection{Kosa with and without deposition of giant dust particles}

For more detailed examination of mismatches between dry deposition and Kosa events shown in Figs. 4 and 5, we compare the temporal variations of dry deposition flux at Tottori and daily mass concentrations of $\mathrm{PM}_{10}$ (red line) and $\mathrm{PM}_{2.5}$ (green line; both from Network Center for EANET, $2009,2011,2012)$ at Oki Island located about $120 \mathrm{~km}$ upstream (WNW) from Tottori (Fig. 6). The difference between $\mathrm{PM}_{10}$ and $\mathrm{PM}_{2.5}$ corresponds to coarse particle concentration 


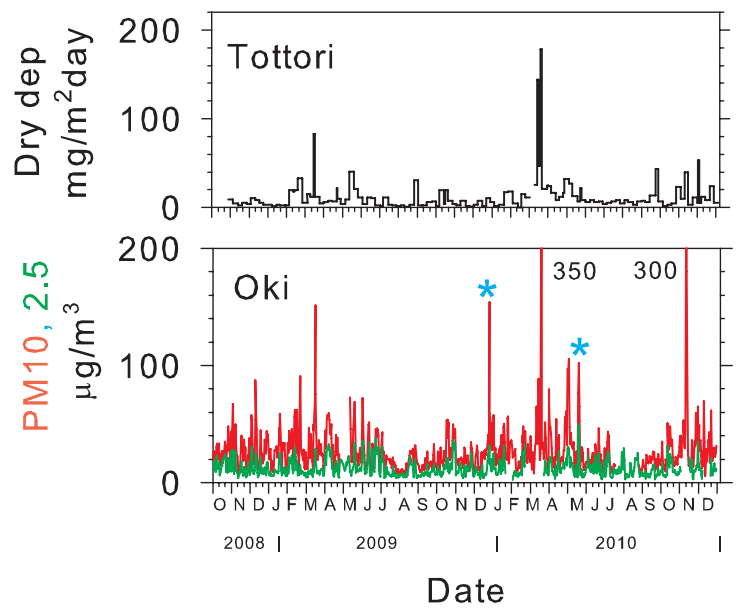

Fig. 6. Upper panel, dry deposition flux $\left(\mathrm{mg} \mathrm{m}^{-2}\right.$ day $\left.{ }^{-1}\right)$ of mineral dust at Tottori; lower panel, daily average concentrations of $\mathrm{PM}_{10}$ and $\mathrm{PM}_{2.5}$ at Oki Island (EANET). Blue asterisks denote days of high $\mathrm{PM}_{10}$ concentrations but with low dry deposition flux.

$\left(\mathrm{PM}_{10}-\mathrm{PM}_{2.5}=\mathrm{PM}_{\mathrm{c}}\right)$. Mass median aerodynamic diameters of Kosa particles in the air near the ground in Japan were typically reported at about $4 \mu \mathrm{m}$ (Ishizaka and Ono, 1982; Mori et al., 2003). Therefore, a higher $\mathrm{PM}_{\mathrm{c}}$ concentration implies a Kosa event condition. In fact, high dry deposition fluxes were observed mostly on days of high $\mathrm{PM}_{\mathrm{c}}$ concentrations such as 17 March 2009 and 21 March 2010. In contrast, dry deposition fluxes were not so high for periods of 26 December 2009 and 21-22 May 2010 (peaks with asterisks), although high $\mathrm{PM}_{\mathrm{c}}$ concentrations were observed and Kosa events were reported at Matsue for these days, which are good examples of a mismatch between deposition and low visibility. We will discuss details of differences of these events.

Figure 7 presents details of the events in 2009 (upper part) and 2010 (lower part). In both parts, upper panels represent time-height sections of extinction coefficient of dust particles observed by lidar (http://www-lidar.nies.go.jp/index. html.en) at Matsue, middle panels show dry deposition fluxes at Tottori, and lower panels depict $\mathrm{PM}_{2.5}$ and $\mathrm{PM}_{10}$ at Oki. The extinction coefficient of dust particles was estimated using the method described by Shimizu et al. (2004). Matsue is located about $110 \mathrm{~km}$ west of Tottori, as shown in the inset map (blue rectangle) of Fig. 1. As Fig. 7 shows, high extinction coefficients of dust particles were observed at the lower troposphere during the events of high $\mathrm{PM}_{10}$ concentrations near ground level. Although the maximum heights of dust layers for high dust deposition fluxes with high $\mathrm{PM}_{10}$ events in March were both higher than $2 \mathrm{~km}$, those for low dust deposition fluxes with high $\mathrm{PM}_{10}$ events on 26 December 2009 and 21 May 2010 were below $2 \mathrm{~km}$. For events of mid-March and end-December of 2009, a similar tendency of time-height dust data was widely observed at other windward lidar sites such as those at Beijing, Seoul, and Fukue (Sugimoto et al., 2013), suggesting that dust particles of
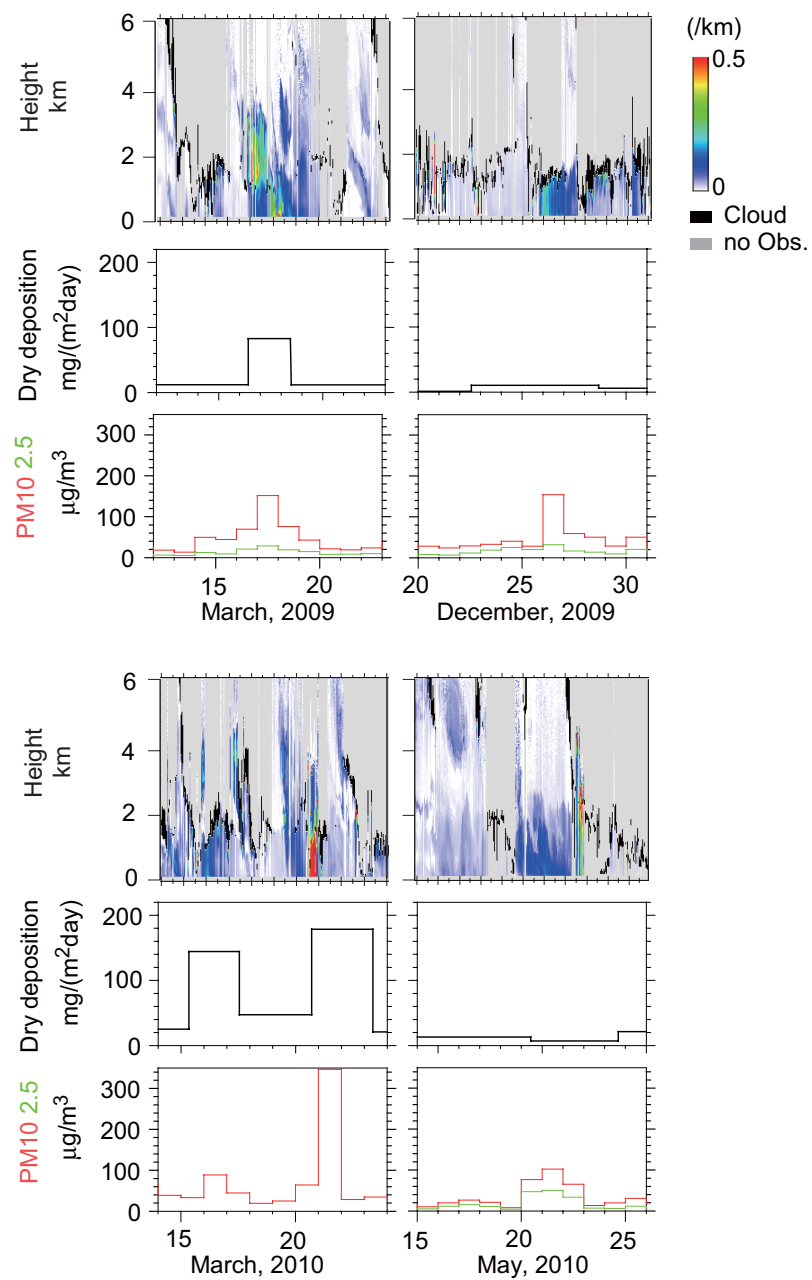

Fig. 7. Comparison of high $\mathrm{PM}_{10}$ events with high (left) and low (right) dry deposition events in 2009 (upper part) and 2010 (lower part). Upper panels of the year show time-height sections of extinction coefficient of dust particles based on lidar measurements at Matsue (NIES web site: http://www-lidar.nies.go.jp/index.html.en). Black and gray shading respectively represent clouds and height ranges of no data. Horizontal black lines in middle panels represent dry deposition flux of dusts at Tottori. Red and green horizontal lines in lower panels show $\mathrm{PM}_{10}$ and $\mathrm{PM}_{2.5}$ concentrations at Oki Island (EANET).

these events were transported through thick ( $>2 \mathrm{~km})$ and thin $(<2 \mathrm{~km})$ layers, respectively, over a long distance. The correspondence of transport height and dry deposition flux imply that the maximum height or thickness of a dust layer is an important restrictive factor for the long-range transport of dust particles. We will further discuss the linkage between the dust layer thickness and deposition flux based on analysis of deposited dust particle size. 

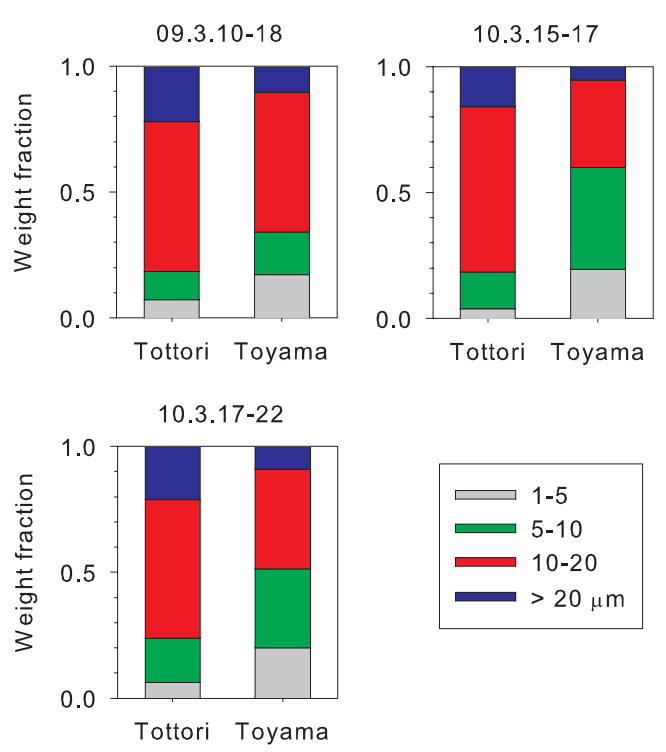

Fig. 8. Weight fraction of size-segregated refractory dust deposited by wet processes. Sampling periods are shown at the top of each panel as yy.mm.dd-dd.

\subsection{Deposition of giant dust particles and transport processes}

Figures 8 and 9 respectively show weight fractions of refractory dust particles for wet and dry deposition samples. Events shown in Figs. 8 and 9 were selected for samples of high refractory weight (about $>1 \mathrm{mg}$ ). As discussed in Fig. 2, precipitation is brought by movement of synoptic scale mid-latitude cyclone and winter monsoon at Tottori and Toyama. For wet samples in Fig. 8, major precipitation events by mid-latitude cyclone systems were observed on 13-14 March 2009, 16 March 2010, and 21 March 2010. Drizzle rains were also frequently observed. Sampling sites in the figures are depicted from west (Fukuoka) to east (Tottori and Toyama), standing at shorter (left) to longer (right) distance from the source areas. Giant fractions (the sum of $>20 \mu \mathrm{m}$ and $10-20 \mu \mathrm{m}$ ) were higher than 0.5 for most of the event samples. Weight fractions of $1-10 \mu \mathrm{m}$ were somewhat larger at Toyama, especially for wet deposition samples. Although proportions of giant fractions for dry deposition were slightly larger than those for wet deposition, the proportional tendency of weight fraction on dry deposition samples was similar to that of wet deposition, implying that our dry deposition samplers collect dust particles over a wide size range. Irrespective of the deposition type, the giant fractions were generally decreasing with travel to the east or increasing distance from the source area, suggesting depletion of giant particles during transport. A minor exception to the spatial tendency was the dry deposition event on 15-17 March 2010, which might be attributable to a shift of main dust stream toward Tottori according to lower visibility at Tottori than at Fukuoka.
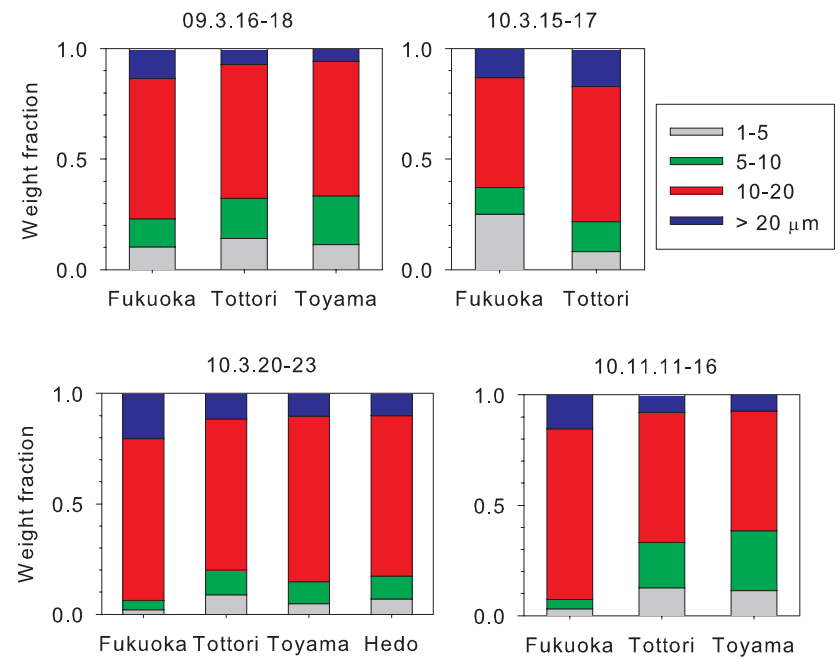

Fig. 9. Weight fraction of size-segregated refractory dust deposited by dry processes Sampling periods are shown at the top of each panel as yy.mm.dd-dd.

Shifting the size fraction of dust particles is attributable to differences in settling velocity with size. For a dust event in March 2001, Mori et al. (2003) reported aerodynamic mass size distributions sampled at Beijing, China, and at Yamaguchi, $1500 \mathrm{~km}$ downwind from Beijing, western Japan. Although the major peak of aerodynamic mass size distribution at Beijing was found at 4.7-7.0 $\mu \mathrm{m}$, the peak in coarse mode at Yamaguchi was 3.3-4.7 $\mu \mathrm{m}$. Assuming that the shift was attributed to solely dry processes, larger and heavier particles can be deposited earlier during their transport. In contrast to the modal diameter of about $4 \mu \mathrm{m}$ in the lower atmosphere at western Japan (Mori et al., 2003), the modal diameter of deposited dust particles is expected to be much larger than that in the atmosphere. Applying a relation (about $\times 4$ of modal diameter in the atmosphere) obtained at Hawaii by Schneider et al. (1990), we obtain $16 \mu \mathrm{m}$ as a mass median diameter of dry deposited dusts, which agrees with high fraction found in $10-20 \mu \mathrm{m}$ of Fig. 9.

Figure 10 shows backward air trajectories for the Kosa events in Fig. 7 over Tottori starting at $700 \mathrm{~m}, 1400 \mathrm{~m}$, and $2100 \mathrm{~m}$ altitudes. The starting altitudes of Fig. 10 approximately represent 1-3 days' duration of gravitational settling for a spherical particle of $10 \mu \mathrm{m}$ with density of $2.6 \mathrm{~g} \mathrm{~cm}^{-3}$ $\left(685 \mathrm{~m} \mathrm{day}^{-1}\right.$; Hinds, 1999). Brown dotted areas in Fig. 10 represent a dust storm region during a one-day to several day period preceding the high $\mathrm{PM}_{10}$ events at Tottori. For these altitude ranges, air masses at lower altitudes generally moved slower than at higher altitudes. For example, air masses at $700 \mathrm{~m}$ and $2100 \mathrm{~m}$ above Tottori on 03:00 UT of 17 March 2009 took about 2 days and 1 day, respectively, to reach dust storm regions. Considering the dust settling velocity estimated above, most of the mass fraction $(68 \%$ for $>10 \mu \mathrm{m}$ ) found in the sample of 16-18 March 2009 in Fig. 9 

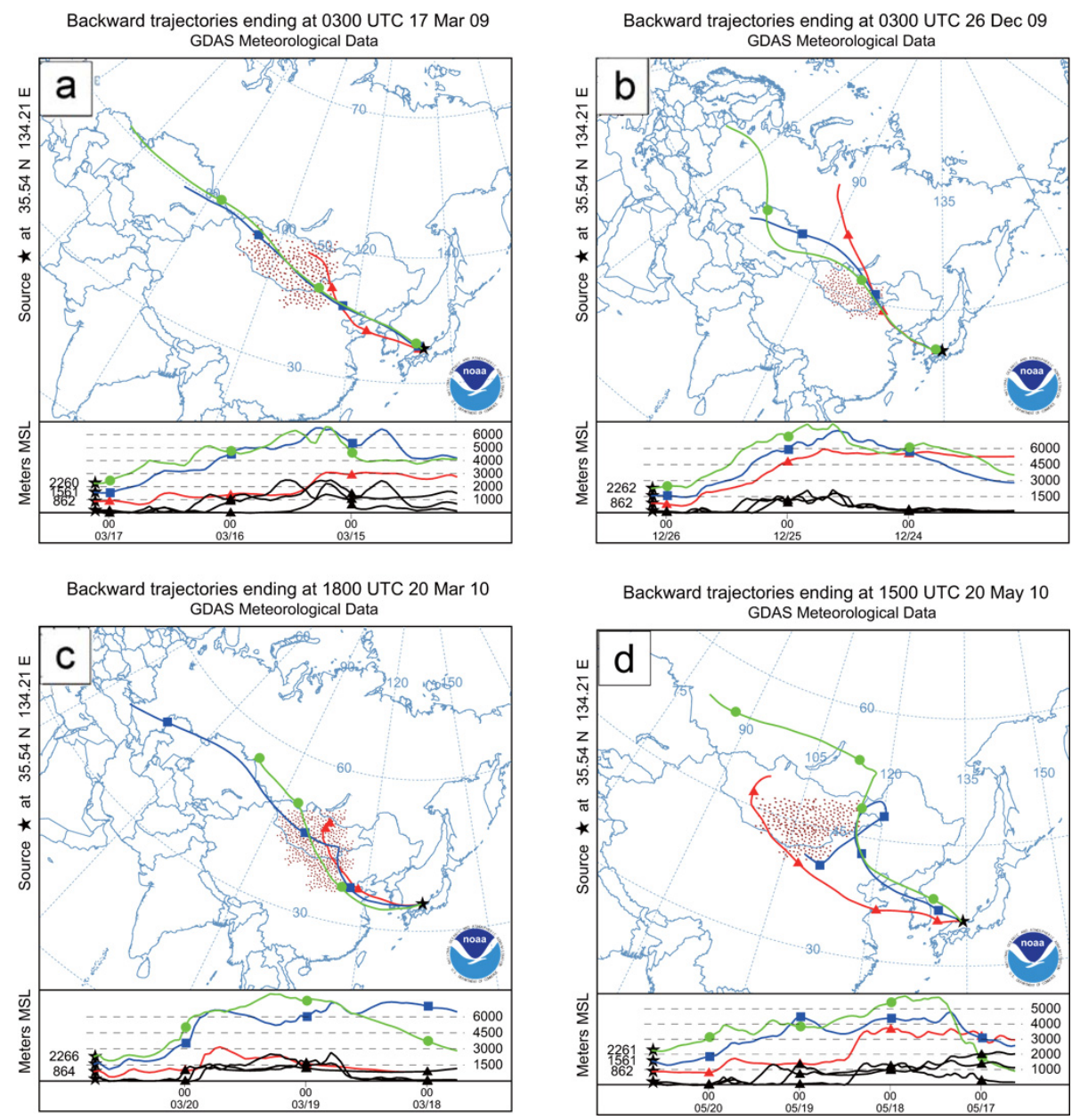

Fig. 10. (a, b, and c) $72 \mathrm{~h}$ and (d) $96 \mathrm{~h}$ backward trajectories of air masses for events in Fig. 7, starting at 700 (red), 1400 (blue), and 2100 (green) $\mathrm{m}$ above ground level over Tottori using the HYSPLIT model (Draxler and Rolph, 2013, http://ready.arl.noaa.gov/HYSPLIT.php). Symbols of trajectories denote positions at 00:00 UT. The brown dotted area represents low visibility (dust storm) area based on the WMO SYNOP observations (http://www.nrlmry.navy.mil/aerosol/).

is probably transported higher than $700 \mathrm{~m}$ because giant dust particles transported below $700 \mathrm{~m}$ were mostly depleted by gravitational settling by the time they reach Japan. Therefore, transport at higher altitudes and at higher horizontal speeds is expected to increase the potential for delivering larger and heavier dust particles to Japan. Asian dust particles are transported at various altitudes (Shimizu et al., 2004; Liu et al., 2008). However, aerosol scale heights of dust transport have been reported as about 2-3 km (Shimizu et al., 2004; Yu et al., 2010). For the lower troposphere near Japan, Itahashi et al. (2010) reported two vertical patterns of dust transport: one is weak stratification (potential temperature gradient of below about $3 \mathrm{~K} \mathrm{~km}^{-1}$ ) with higher and thicker vertical distribution of dust layer (2.5-4 km above ground level), the other is a strong stratification (potential temperature gradient of about $5 \mathrm{~K} \mathrm{~km}^{-1}$ ) with a lower and thinner dust layer within a planetary boundary layer. A similar analysis was reported by Tsai et al. (2008), including mid-tropospheric transport.
Figure 11 portrays vertical profiles of potential temperature at stations near Tottori for the Kosa events shown in Fig. 7. The vertical gradient of potential temperature below $3 \mathrm{~km}$ is low $\left(2.3\right.$ and $\left.3 \mathrm{~K} \mathrm{~km}^{-1}\right)$ in the cases of 17 March 2009 and 21 March 2010, respectively, but high (both $5 \mathrm{~K} \mathrm{~km}^{-1}$ ) in the cases of 26 December 2009 and 21 May 2010. As Fig. 11 shows, strong stratification is consistent with thinner dust distributions on December 2009 and May 2010, as depicted by lidar data in Fig. 7. Under a highly stratified condition, upward vertical mixing is limited and capped within a narrow range. Giant dust particles at a low altitude are depleted by rapid gravitational settling by the time they reach Japan. Therefore, dust particles smaller than $10 \mu \mathrm{m}$ would be expected to remain selectively in the atmosphere because of their lower rate of settling. For example, the settling velocity of a spherical particle of $4 \mu \mathrm{m}$ with density of $2.6 \mathrm{~g} \mathrm{~cm}^{-3}$ is only $112 \mathrm{mday}^{-1}$, which is about six times lower than that for $10 \mu \mathrm{m}$. Therefore, it is easier to survive. However, 


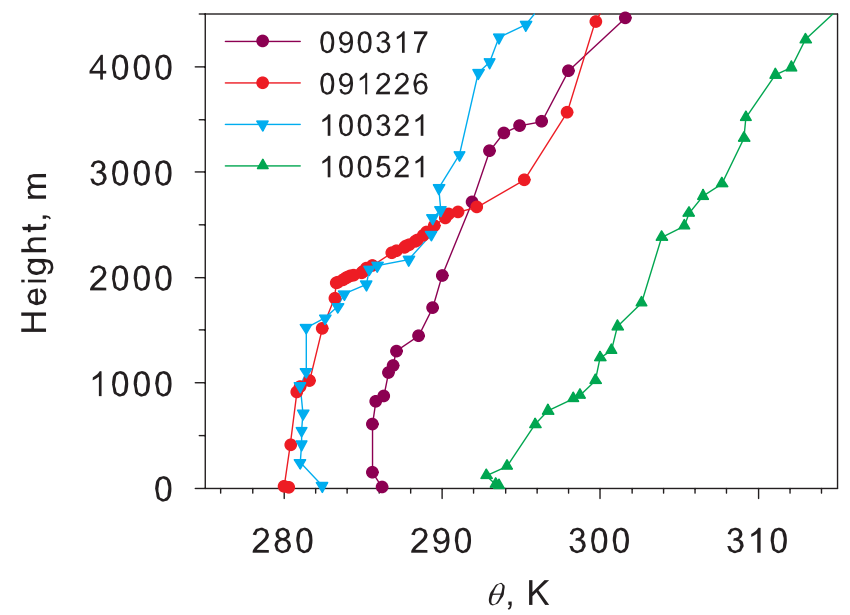

Fig. 11. Vertical profiles of potential temperature at Yonago for 2009 and Matsue for 2010. The upper air observation site was moved from Yonago to Matsue, which are located about 80 and $110 \mathrm{~km}$ west of Tottori. Meteorological data are obtained from the JMA web site (http://www.data.jma.go.jp/obd/stats/etrn/upper/ index.php).

this size of dust particles contributes only slightly to the weight of deposition amount, unless vastly numerous dust particles are deposited, which would take an unrealistically long time for a Kosa event. To reduce visibility, dust particles of $\mathrm{PM}_{\mathrm{c}}(2.5<D<10 \mu \mathrm{m})$ also act as an important contributor of Kosa report based on visibility reduction. This is the reason for high $\mathrm{PM}_{\mathrm{c}}$ with small dust deposition flux that occurred on 26 December 2009 and 21 May 2010.

\subsection{Giant dust deposition and atmospheric transport processes}

This section presents a summary of giant dust deposition at various sites near a source area to the Japanese mountain, and remote Pacific, and presents discussion of their implications for atmospheric transport processes. Based on monthly and seasonal sampling of atmospheric dust deposition at six sites on the Chinese Loess Plateau, Sun et al. (2003) reported that modal diameters of deposited dusts were $20-30 \mu \mathrm{m}$ at all sites. Their sampling sites were close to major source deserts or were potentially located within the area of re-suspension of deposited dust. Therefore, modal diameters in their reports were much greater than in our results. Size measurements of dust particles in dusty snow collected at Mt. Tateyama, central Japan showed modal diameters of about 6-21 $\mu$ m (Osada et al., 2004). Sampling conditions of spring snow at Mt. Tateyama are suitable to avoid local dust contamination. Therefore, their results are regarded as a good reference of the dust size distribution over Japan. Weight fractions in the present study are consistent with size data of snow at Mt. Tateyama. Giant mineral particles were found in the central Pacific near Oahu Island as a result of long-range transport of more than $10000 \mathrm{~km}$ from Asian source regions (Betzer et al., 1988). Their findings were striking in terms of distance ( $>4$ fold compared to our cases) and size (>75 $\mu \mathrm{m}$ ) of dust particles transported, but they did not mention about how often it occurred. In contrast, our data show the frequent deposition of giant dust particles over Japan, suggesting that the transport of giant dust particles is important for the total mass flux to remote oceans, especially in the North Pacific, which is known as an HNLC region.

As described in Sect. 3.1, wet deposition fluxes at Toyama and Tottori were much higher than that in Nagoya where precipitation frequency was low. Because dust particles are transported by westerly wind to the east, and because western sites of the Japanese Islands are influenced by frequent drizzle during dusty seasons, dust particles are depleted during air mass passage over the Japanese archipelago as if dust particles are washed out by precipitation along the western side of the Japanese islands. The distance between Toyama and Nagoya is about $170 \mathrm{~km}$. Therefore, finer horizontal resolution is necessary to simulate the small scale difference of wet deposition properly. Indeed, large-scale transport models have difficulty reproducing the transport of large dust particles (Zendar et al., 2004). Reportedly, a counteracting process to gravitational settling exists for particles of 10$50 \mu \mathrm{m}$ at higher wind speeds, but the mechanism responsible for this phenomenon was not fully understood (Aluko and Noll, 2006). They claim that this can promote their ability for long range transport of giant dust. Another possible process changing vertical dust distribution is the convective transport of dust particles (Jung et al., 2005). Dust size larger than $10 \mu \mathrm{m}$ is important for the mass of wet and dry deposition. Therefore, further analysis and simulation of giant dust particle behavior in the atmosphere is necessary to ascertain actual dust effects on biogeochemical cycles as well as their climatic significance.

\section{Summary and conclusions}

Weekly wet and dry deposition samples at six sites in Japan were obtained during October 2008-December 2010 to study temporal variations and spatial distributions of mineral dust deposition fluxes. Sampling sites were chosen to cover the area from northeast to southwest: Sapporo, Toyama, Nagoya, Tottori, Fukuoka, and Cape Hedo (Okinawa) in Japan. We used automatic wet/dry separating samplers and Fe content of filter residues to estimate mineral dust amounts.

Wet and dry deposition fluxes of mineral dusts were both high in spring and low in summer, presenting similar seasonal variations to the frequency of visibility-reducing aeolian dust events (Kosa) in Japan. For wet deposition, higher annual deposition fluxes were observed at Toyama and Tottori, where frequent precipitation (> $60 \%$ per month) was observed during dusty seasons. Annual wet deposition fluxes at Cape Hedo and Nagoya were much smaller because of 
infrequent precipitation in dusty season. For dry deposition among Toyama, Tottori, Fukuoka, and Cape Hedo, annual dry deposition fluxes were highest at Fukuoka and lowest at Cape Hedo. The average ratio of wet/dry deposition fluxes was the highest at Toyama (3.3) and the lowest at Hedo (0.82), indicating a greater contribution of the dry process at western sites, probably because of (1) distance from desert areas and relative location to main stream of dust transport, and (2) effectiveness of the wet process such as frequent precipitation during the dusty season.

Temporal variations of dry deposition fluxes were compared with the frequency of Kosa events and atmospheric concentrations of coarse particles $\left(\mathrm{PM}_{\mathrm{c}}: 2.5<D<10 \mu \mathrm{m}\right)$. Although higher dry deposition fluxes were generally obtained during frequent Kosa events with higher $\mathrm{PM}_{\mathrm{c}}$, fluxes for some events were not so high during Kosa events. Examination of the vertical distribution of dust particles indicated by Lidar suggests that transport through the shallow (about $<2 \mathrm{~km}$ ) dust layer engendered low dry deposition of dust, although high $\mathrm{PM}_{\mathrm{c}}$ concentrations were observed.

Refractory parts of deposited dust particles were sizesegregated using multiple filters: $>20,>10,>5$, and $>1 \mu \mathrm{m}$ diameter. Weight fractions of giant dust (the sum of $>20 \mu \mathrm{m}$ and $10-20 \mu \mathrm{m}$ ) were higher than $50 \%$ for samples of the most heavy event (>1 mg of refractory weight). Irrespective of deposition type, the giant fractions were generally decreasing concomitantly with increasing distance from the source area, suggesting the selective depletion of larger giant particles during transport.

Vertical profiles of potential temperatures indicated stronger stratification, which is consistent with thinner and lower dust distributions depicted by lidar data. Because giant dust particles at low altitude are depleted by rapid gravitational settling at the time they reach Japan, dust particles smaller than $10 \mu \mathrm{m}$ selectively remain in the atmosphere because of slower settling velocity. Dust particles of $\mathrm{PM}_{\mathrm{c}}$ contribute only slightly to the weight of deposition amount but they can act as an important reducer of visibility. This is a plausible cause of high $\mathrm{PM}_{\mathrm{c}}$ with small dust deposition flux on 26 December 2009 and 21 May 2010.

Combined with the relations of dry deposition flux, dust layer thickness, potential temperature profile, and dust size information, transport through a thicker $(>2 \mathrm{~km})$ dust layer with a weak vertical gradient of potential temperature can carry more giant dust particles to Japan. Because giant dust particles are important mass fractions of dust accumulation, especially in the North Pacific, precise simulation of giant particles in the atmosphere is necessary for the study of dust budgets through the atmosphere, their climatic effects and their roles in biogeochemical cycles.
Acknowledgements. We are grateful to Y. Takeda in Cape Hedo, H. Sasaki in Sapporo, T. Nakayama and Y. Kobayashi in Toyama, T. Maruyama and A. Naganuma in Fukuoka, A. Kato and A. Abulaiti in Tottori, and K. Kawakita and S. Ueda in Nagoya for helping with sample collection of dust deposition. We also thank Y. Hara at Kyusyu University for helpful discussions. Data of $\mathrm{PM}_{10}$ and $\mathrm{PM}_{2.5}$ at Oki were provided by Acid Deposition Monitoring Network in East Asia (EANET) (http://www.eanet.asia/product/index.html). The authors gratefully acknowledge the NOAA Air Resources Laboratory (ARL) for providing the HYSPLIT transport and dispersion model and/or READY website (http://www.ready.noaa.gov) used in this publication. This research was financially supported by Grants-in-Aid for Scientific Research (A) (20244078) and (B) (20310009), and a Grant-in-Aid for Scientific Research in Priority Areas, Grant No. 18067005 (W-PASS), provided by the Ministry of Education, Culture, Sports, Science and Technology, Japan. This research, a contribution of IGBP/SOLAS activity, was also supported by the Environment Research and Technology Development Fund (5B-1202) of the Ministry of the Environment, Japan.

Edited by: Y.-S. Chung

\section{References}

Aluko, O. and Noll, K. E.: Deposition and suspension of large, airborne particles, Aerosol Sci. Tech., 40, 503-513, 2006.

Arao, K., Itou, K., and Koja, A.: Secular variation of Yellow sand dust events over Nagasaki in Japan: 1914-2001, J. Environ. Studies, Nagasaki University, 5, 1-10, 2003 (in Japanese).

Aoki, T., Motoyoshi, H., Kodama, Y., Yasunari, T. J., Sugiura, K., and Kobayashi, H.: Atmospheric aerosol deposition on snow surfaces and its effect on albedo, SOLA, 2, 13-16, doi:10.2151/sola.2006-004, 2006.

Barry, R. G. and Chorley, R. J.: Atmosphere, weather and climate, Eighth Edn., Routledge, London, p. 421, 2003.

Betzer, P. R., Carder, K. L., Duce, R. A., Merrill, J. T., Tindale, N. W., Uematsu, M., Costello, D. K., Young, R. W., Feely, R. A., Breland, J. A., Bernstein R. E., and Greco, A. M.: Long-range transport of giant mineral aerosol particles, Nature, 336, 568571, doi:10.1038/336568a0, 1988.

Bian, H., Tie, X., Cao, J., Ying, Z., Han, S., and Xue, Y.: Analysis of a Severe Dust Storm Event over China: Application of the WRFDust Model, Aerosol Air Qual. Res., 11, 419-428, 2011.

Cao, J. J., Chow, J. C., Watson, J. G., Wu, F., Han, Y. M., Jin, Z. D., Shen, Z. X., and An, Z. S.: Size-differentiated source profiles for fugitive dust in the Chinese Loess Plateau, Atmos. Environ., 42, 2261-2275, 2008.

Choi, J. C., Lee, M., Chun, Y., Kim, J., and Oh, S.: Chemical Composition and Source Signature of Spring Aerosol in Seoul, Korea, J. Geophys. Res.-Atmos., 106, 18067-18074, 2001.

Draxler, R. R. and Rolph, G. D.: HYSPLIT (HYbrid Single-Particle Lagrangian Integrated Trajectory) Model access via NOAA ARL READY Website http://www.arl.noaa.gov/HYSPLIT.php (last access: 29 January 2014), NOAA Air Resources Laboratory, College Park, MD, 2013.

Duce, R. A., Liss, P. S., Merrill, J. T., Atlas, E. L., Buat-Menard, P., Hicks, B. B., Miller, J. M., Prospero, J. M., Arimoto, R., Church, T. M., Ellis, W., Galloway, J. N., Hansen, L., Jickells, T. D., 
Knap, A. H., Reinhardt, K. H., Schneider, B., Soudine, A., Tokos, J. J., Tsunogai, S., Wollast, R., and Zhou, M.: The atmospheric input of trace species to the world ocean, Global Biogeochem. Cy., 5, 193-259, 1991.

Feng, J.-L., Zhu, L.-P., Ju, J.-T., Zhou, L.-P., Zhen, X.-L., Zhang, W., and Gao, S.-P.: Heavy Dust Fall in Beijing, on April 1617, 2006: Geochemical Properties and Indications of the Dust Provenance, Geochem. J., 42, 221-236, 2008.

Formenti, P., Nava, S., Prati, P., Chevaillier, S., Klaver, A., Lafon, S., Mazzei, F., Calzolai, G., and Chiari, M.: Self-attenuation artifacts and correction factors of light element measurements by Xray analysis: Implication for mineral dust composition studies, J. Geophys. Res., 115, D01203, doi:10.1029/2009JD012701, 2010.

Formenti, P., Schütz, L., Balkanski, Y., Desboeufs, K., Ebert, M., Kandler, K., Petzold, A., Scheuvens, D., Weinbruch, S., and Zhang, D.: Recent progress in understanding physical and chemical properties of African and Asian mineral dust, Atmos. Chem. Phys., 11, 8231-8256, doi:10.5194/acp-11-8231-2011, 2011.

Ganor, E., Foner, H. A., and Gravenhorst, G.: The amount and nature of the dustfall on Lake Kinneret (the Sea of Galilee), Israel: flux and fractionation, Atmos. Environ., 37, 4301-4315, 2003.

Goossens, D.: Quantification of the dry aeolian deposition of dust on horizontal surfaces: an experimental comparison of theory and measurements, Sedimentology, 52, 589-873, 2005.

Goossens, D.: Bias in grain size distribution of deposited atmospheric dust due to the collection of particles in sediment catchers, CATENA, 70, 16-24, 2007.

Goossens, D. and Rajot, J. L.: Techniques to measure the dry aeolian deposition of dust in arid and semi-arid landscapes: a comparative study in West Niger, Earth Surf. Proc. Land., 33, 178195, 2008

Hinds, W. C.: Aerosol Technology, John Wiley \& Sons, New York, 483 pp., 1999.

Hsu, S.-C., Liu, S. C., Arimoto, R., Liu, T.-H., Huang, Y.-T., Tsai, F., Lin, F.-J., and Kao, S.-J.: Dust deposition to the East China Sea and its biogeochemical implications, J. Geophys. Res., 114, D15304, doi:10.1029/2008JD011223, 2009.

Huneeus, N., Schulz, M., Balkanski, Y., Griesfeller, J., Prospero, J., Kinne, S., Bauer, S., Boucher, O., Chin, M., Dentener, F., Diehl, T., Easter, R., Fillmore, D., Ghan, S., Ginoux, P., Grini, A., Horowitz, L., Koch, D., Krol, M. C., Landing, W., Liu, X., Mahowald, N., Miller, R., Morcrette, J.-J., Myhre, G., Penner, J., Perlwitz, J., Stier, P., Takemura, T., and Zender, C. S.: Global dust model intercomparison in AeroCom phase I, Atmos. Chem. Phys., 11, 7781-7816, doi:10.5194/acp-11-7781-2011, 2011.

Imai, N., Terashima, S., Itoh, S., and Ando, A.: compilation of analytical data on nine GSJ Geochemical Reference samples, sedimentary rock series, Geostandard. Newslett., 20, 165-216, 1996.

Inomata, Y., Igarashi, Y., Mikami, M., Tanaka, T. Y., and Chiba, M.: Seasonal and yearly variations of dust deposition in Tsukuba: Possible linkage with variations of dust emission over the Asian continent, SOLA, 5, 153-155, 2009a.

Inomata, Y., Igarashi, Y., Chiba, M., Shinoda, Y., and Takahashi, H.: Dry and wet deposition of water-insoluble dust and water-soluble chemical species during spring 2007 in Tsukuba, Japan, Atmos. Environ., 43, 4503-4512, 2009b.

Inoue, K. and Naruse, T.: Physical, chemical, and mineralogical characteristics of modern eolian dust in Japan and rate of dust deposition, Soil Sci. Plant Nutr., 33, 327-345, 1987.
Ishizaka, Y. and Ono, A.: Mass size distribution of the principal minerals of yellow sand dust in the air over Japan, Idojaras, 86, 249-253, 1982.

Itahashi, S., Yumimoto, K., Uno, I., Eguchi, K., Takemura, T., Hara, Y., Shimizu, A., Sugimoto, N., and Liu Z.: Structure of dust and air pollutant outflow over East Asia in the spring, Geophys. Res. Lett., 37, L20806, doi:10.1029/2010GL044776, 2010.

Jeong, G. Y.: Bulk and Single-Particle Mineralogy of Asian Dust and a Comparison with Its Source Soils, J. Geophys. Res.Atmos., 113, 2208, doi:10.1029/2007JD008606, 2008.

Jickells, T. D., An, Z. S., Andersen, K. K., Baker, A. R., Bergametti, G., Brooks, N., Cao, J. J., Boyd, P. W., Duce, R. A., Hunter, K. A., Kawahata, H., Kubilay, N., laRoche, J., Liss, P. S., Mahowald, N., Prospero, J. M., Ridgwell, A. J., Tegen, I., and Torres, R.: Global iron connections between desert dust, ocean biogeochemistry, and climate, Science, 308, 67-71, 2005.

Jung, E., Shao, Y. and Sakai, T.: A study on the effects of convective transport on regional-scale Asian dust storms in 2002, J. Geophys. Res., 110, D20201, doi:10.1029/2005JD005808, 2005.

Kinoshita, A. and Maki, T.: Real time information and forcast model for Kosa (Asian dust) by Japan Meteorological Agency, Tenki, 56, 71-76, 2009 (in Japanese).

Koizumi, K.: Studies on KOSA, part 1, Kokumin Eisei (National Hygiene of Japan), 9, 983-1026, 1932 (in Japanese).

Li, J., Han, Z., and Zhang, R.: Model study of atmospheric particulates during dust storm period in March 2010 over East Asia, Atmos. Environ., 45, 3954-3964, 2011.

Lin, C.-Y., Sheng, Y.-F., Chen, W.-N., Wang, Z., Kuo, C.-H., Chen, W.-C., and Yang, T.: The impact of channel effect on Asian dust transport dynamics: a case in southeastern Asia, Atmos. Chem. Phys., 12, 271-285, doi:10.5194/acp-12-271-2012, 2012.

Liu, D., Wang, Z., Liu, Z., Winker, D., and Trepte, C.: A height resolved global view of dust aerosols from the first year CALIPSO lidar measurements, J. Geophys. Res., 113, D16214, doi:10.1029/2007JD009776, 2008.

Lovett, G. M.: Atmospheric deposition of nutrients and pollutants in North America: An ecological perspective, Ecol. Appl., 4, 629_ 650, 1994.

Loye-Pilot, M. D. and Martin, J. M.: Saharan dust input to the western Mediterranean: An eleven years record in Corsica, in The impact of desert dust across the Mediterranean, edited by: Guerzoni, S. and Chester, R., 191-199, Kluwer Academic, the Netherlands, 1996.

Lue, Y. L., Liu, L. Y., Hu, X., Wang, L., Gao, S. Y., Zhang, X. X., Tang, Y., Qu, Z. Q., Cao, H. W., Jia, Z. J., Xu, H. Y., and Yang, Y. Y.: Characteristic and Provenance of Dustfall during an Unusual Floating Dust Event, Atmos. Environ., 44, 3477-3484, 2010.

Mahowald, N. M., Baker, A. R., Bergametti, G., Brooks, N., Duce, R. A., Jickells, T. D., Kubilay, N., Prospero, J. M., and Tegen, I.: Atmospheric global dust cycle and iron inputs to the ocean, Global Biogeochem. Cy., 19, GB4025, doi:10.1029/2004GB002402, 2005.

McTanish, G. and Strong, C.: The role of aeolian dust in ecosystems, Geomorphology, 89, 39-54, 2007.

Mona, L., Liu, Z., Muller, D., Omar, A., Papayannis, A., Pappalardo, G., Sugimoto, N., and Vaughan, M.: Lidar Measurements for Desert Dust Characterization: An Overview, Adv. Meteorol., 2012, 36 pp., doi:10.1155/2012/356265, 2012 
Mori, I., Nishikawa, M., Tanimura, T., and Quan, H.: Change in size distribution and chemical composition of kosa (Asian dust) aerosol during long-range transport, Atmos. Environ., 37, 42534263, 2003.

Network Center for EANET: Data Report on the Acid Deposition in the East Asian Region 2008, 318 pp., 2009.

Network Center for EANET: Data Report on the Acid Deposition in the East Asian Region 2009, 313 pp., 2011.

Network Center for EANET: Data Report on the Acid Deposition in the East Asian Region 2010, 313 pp., 2012.

Nihlén, T., Mattsson, J. O., Rapp, A., Gagaoudaki, C., Kornaros, G., and Papageorgiou, J.: Monitoring of Saharan dust fallout on Crete and its contribution to soil formation, Tellus, 47, 365-374, 1995.

Nishikawa, M., Kanamori, S., Kanamori, N., and Mizoguchi, T.: Kosa aerosol as aeolian carrier of anthropogenic material, Sci. Total Environ., 107, 13-27, 1991.

Offer, Z. and Goossens, D.: Thirteen years of aeolian dust dynamics in a desert region (Negev desert, Israel): analysis of horizontal and vertical dust flux, vertical dust distribution and dust grain size, J. Arid Environ., 57, 117-140, 2004.

Okin, G. S., Mahowald, N., Chadwick, O. A., and Artaxo P.: Impact of desert dust on the biogeochemistry of phosphorus in terrestrial ecosystems, Global Biogeochem. Cy., 18, GB2005, doi:10.1029/2003GB002145, 2004.

Onishi, K., Kurosaki, Y., Otani, S., Yoshida, A., Sugimoto, N., and Kurozawa, Y.: Atmospheric transport route determines components of Asian dust and health effects in Japan, Atmos. Environ., 49, 94-102, doi:10.1016/j.atmosenv.2011.12.018, 2012.

Osada, K., Iida, H., Kido, M., Matsunaga, K., and Iwasaka, Y.: Mineral Dust Layers in Snow at Mt. Tateyama, Central Japan: Formation Processes and Characteristics, Tellus, 56, 382-392, 2004.

Osada, K., Ura, S., Kagawa, M., Mikami, M., Tanaka, T. Y., Matoba, S., Aoki, K., Shinoda, M., Kurosaki, Y., Hayashi, M., Shimizu, A., and Uematsu, M.: Temporal and spatial variations of wet deposition flux of mineral dust in Japan, SOLA, 7, 49-52, 2011.

Pye, K.: Aeolian dust transport and deposition over Crete and adjacent parts of the Mediterranian Sea, Earth Surf. Proc. Land., 17, 271-288, 1992.

Reheis, M. C.: A 16-year record of eolian dust in Southern Nevada and California, USA: Controls on dust generation and accumulation, J. Arid Environ., 67, 487-520, 2006.

Schneider, B. N., Tindale, W., and Duce, R. A.: Dry deposition of Asian mineral dust over the central North Pacific, J. Geophys. Res.-Atmos., 95, 9873-9878, 1990.

Schroth, A. W., Crusius, J., Sholkovitz, E. R., and Bostick, B. C.: Iron solubility driven by speciation in dust sources to the ocean, Nat. Geosci., 2, 337-340, doi:10.1038/ngeo501, 2009.

Schulz, M., Prospero, J. M., Baker, A. R., Dentener, F., Ickes, L., Liss, P. S., Mahowald, N. M., Nickovic, S. C., Garcia-Pando, P., Rodriguez, S., Sarin, M., Tegen, I., and Duce, R. A.: Atmospheric Transport and Deposition of Mineral Dust to the Ocean: Implications for Research Needs, Environ. Sci. Technol., 46, 1039010404, doi:10.1021/es300073u, 2012.

Seinfeld, J. H. and Pandis, S. N.: Dry Deposition, in: Atmospheric Chemistry and Physics, Second Edn., John Wiley \& Sons, Hoboken, 900-931, 2006.

Shao, Y., Wyrwoll, K.-H., Chappell, A., Huang, J., Lin, Z., McTainsh, G. H., Mikami, M., Tanaka, T. Y., Wang, X., and Yoon,
S.: Dust cycle: An emerging core theme in Earth system science, Aeolian Res., 2, 181-204, 2011.

Shimizu, A., Sugimoto, N., Matsui, I., Arao, K., Uno, I., Murayama, T., Kagawa, N., Aoki, K., Uchiyama, A., and Yamazaki, A.: Continuous observations of Asian dust and other aerosols by polarization lidar in China and Japan during ACE - Asia, J. Geophys. Res., 109, D19S17, doi:10.1029/2002JD003253, 2004.

Sow, M., Goossens, D., and Rajot, J. L.: Calibration of the MDCO dust collector and of four versions of the inverted frisbee dust deposition sampler, Geomorphology, 82, 360-375, 2006.

Su, L. and Toon, O. B.: Saharan and Asian dust: similarities and differences determined by CALIPSO, AERONET, and a coupled climate-aerosol microphysical model, Atmos. Chem. Phys., 11, 3263-3280, doi:10.5194/acp-11-3263-2011, 2011.

Sugimoto, N., Hara, Y., Shimizu, A., Nishizawa, T., Matsui, I., and Nishikawa, M.: Analysis of dust events in 2008 and 2009 using the lidar network, surface observations and the CFORS model, Asia-Pacific J. Atmos. Sci., 49, 27-39, 2013.

Sun, D., Chen, F., Bloemendal, J., and Su, R.: Seasonal variability of modern dust over the Loess Plateau of China, J. Geophys. Res., 108, 4665, doi:10.1029/2003JD003382, 2003.

Ta, W., Xiao, H., Qu, J., Xiao, Z., Yang, G., Wang, T., and Zhang, X.: Measurements of dust deposition in Gansu Province, China, 1986-2000, Geomorphology, 57, 41-51, 2004.

Tai, H.-S., Lin, J. J., and Noll, K. E.: Characterization of atmospheric dry deposited particles at urban and non-urban locations, J. Aerosol Sci., 30, 1057-1068, 1999.

Takemura, T., Okamoto, H., Maruyama, Y., Numaguti, A., Higurashi, A., and Nakajima, T.: Global three-dimensional simulation of aerosol optical thickness distribution of various origins, J. Geophys. Res.-Atmos., 105, 17853-17873, 2000.

Tanaka, T. Y., Orito, K., Sekiyama, T. T., Shibata, K., Chiba, M., and Tanaka, H.: MASINGAR, a global tropospheric aerosol chemical transport model coupled with MRI/JMA98 GCM: Model description, Pap. Meteorol. Geophys., 53, 119-138, 2003.

Tatarov, B., Müller, D., Noh, Y.-M., Lee, K.-H., Shin, D.H., Shin, S.-K., Sugimoto, N., Seifert, P., and Kim, Y.-J.: Record heavy mineral dust outbreaks over Korea in 2010: Two cases observed with multiwavelength aerosol/depolarization/Raman-quartz lidar, Geophys. Res. Lett., 39, L14801, doi:10.1029/2012GL051972, 2012.

Taylor, S. R. and McLennan, S. M.: The geochemical evolution of the continental crust, Rev. Geophys., 33, 241-265, 1995.

Tegen, I.: Modeling the mineral dust aerosol cycle in the climate system, Quaternary Sci. Rev., 22, 1821-1834, 2003.

Terashima, S., Imai, N., Taniguchi, M., Okai, T., and Nishimura, A.: The preparation and preliminary characterization of four new geological survey of Japan geochemical reference materials: soils, JSO-1 and JSO-2; and marine sediments, JMS-1 and JMS-2, Geostandard. Newslett., 26, 85-94, 2002.

Tsai, F., Chen, G. T.-J., Liu, T.-H., Lin, W.-D., and Tu, J.-Y.: Characterizing the transport pathways of Asian dust, J. Geophys. Res., 113, D17311, doi:10.1029/2007JD009674, 2008.

Uematsu, M., Duce, R. A., and Prospero, J. M.: Deposition of atmospheric mineral particles in the north Pacific Ocean, J. Atmos. Chem., 3, 123-138, 1985.

Uematsu, M., Wang, Z., and Uno, I.: Atmospheric input of mineral dust to the western North Pacific region based on direct measure- 
ments and a regional chemical transport model, Geophys. Res. Lett., 30, 1342, doi:10.1029/2002GL016645, 2003.

Ura, S., Osada, K., Kagawa, M., Mikami, M., Matoba, S., Aoki, K., Shinoda, M., Kurosaki, Y., Hayashi, H., Shimizu, A., and Uematsu, M.: Estimation of mineral dust amount using Fe content in water-insoluble residue of atmospheric deposition samples, (in Japanese with English abstract), Earozoru Kenkyu, 26, 234-241, 2011.

Uno, I., Carmichael, G. R., Streets, D. G., Tang, Y., Yienger, J. J., Satake, S., Wang, Z., Woo, J.-H., Guttikunda, S., Uematsu, M., Matsumoto, K., Tanimoto, H., Yoshioka, K., and Iida, T.: Regional chemical weather forecasting system CFORS: Model descriptions and analysis of surface observations at Japanese island stations during the ACE - Asia experiment, J. Geophys. Res., 108, 8668, doi:10.1029/2002JD002845, 2003.

Uno, I., Wang, Z., Chiba, M., Chun, Y. S., Gong, S. L., Hara, Y., Jung, E., Lee, S.-S., Liu, M., Mikami, M., Music, S., Nickovic, S., Satake, S., Shao, Y., Song, Z., Sugimoto, N., Tanaka, T., and Westphal, D. L.: Dust model intercomparison (DMIP) study over Asia: Overview, J. Geophys. Res.-Atmos., 111, D12213, doi:10.1029/2005JD006575, 2006.

Vallack, H. W. and Chadwick, M. J.: A field comparison of dust deposit gauge performance at two sites in Yorkshire, 1987-1989, Atmos. Environ., 26, 1445-1451, 1992.

Wang, S.-H., Tsay, S.-C., Lin, N.-H., Hsu, N. C., Bell, S. W., Li, C., Ji, Q., Jeong, M.-J., Hansell, R. A., Welton, E. J., Holben, B. N., Sheu, G.-R., Chu, Y.-C., Chang, S.-C., Liu, J.-J., and Chiang, W.-L.: First detailed observations of long-range transported dust over the northern South China Sea, Atmos. Environ., 45, 48044808, 2011

Washington, R. and Wiggs, G. S. F.: Desert dust, in Arid Zone Geomorphology: Process, Form and Change in Dynamics, Third edition, edited by: Thomas, D. S. G., John Wiley \& Sons, 517-537, 2011.
Wu, F., Chow, J. C., An, Z., Watson, J. G., and Cao, J.: SizeDifferentiated Chemical Characteristics of Asian Paleo Dust: Records from Aeolian Deposition on Chinese Loess Plateau, JAPCA J. Air Waste Ma., 61, 180-189, 2011.

Yabuki, S., Mikami, M., Nakamura, Y., Kanayama, S., Fu, F., Liu, M., and Zhou, H.: The characteristics of atmospheric aerosol at Aksu, an Asian dust-source region of north-west China: A summary of observations over the three years from March 2001 to April 2004, J. Meteorol. Soc. Jpn., 83, 45-72, 2005.

Yamaguchi, Y. and Takemura, T.: Interannual variation of observation time on haze and Kosa, Tenki, 58, 965-968, 2011 (in Japanese).

Yu, H., Chin, M., Winker, D. M., Omar, A. H., Liu, Z., Kittaka, C., and Diehl, T.: Global view of aerosol vertical distributions from CALIPSO lidar measurements and GOCART simulations: Regional and seasonal variations, J. Geophys. Res., 115, D00H30, doi:10.1029/2009JD013364, 2010.

Zender, C. S., Miller, R. L., and Tegen, I.: Quantifying mineral dust mass budgets: Terminology, constraints, and current estimates, EOS, 85, 509-512, doi:10.1029/2004EO480002, 2004.

Zhang, J., Liu, S. M., and Huang, W. W.: Characterizing Asian wind-dust transport to the Northwest Pacific Ocean. Direct measurements of the dust flux for two years, Tellus, 45, 335-345, 1993.

Zufall, M. J. and Davidson, C. I.: Dry deposition of particles, in: Atmospheric Particles, edited by: Harrison, R. M. and Van Grieken, R., John Wiley \& Sons, 425-473, 1998. 